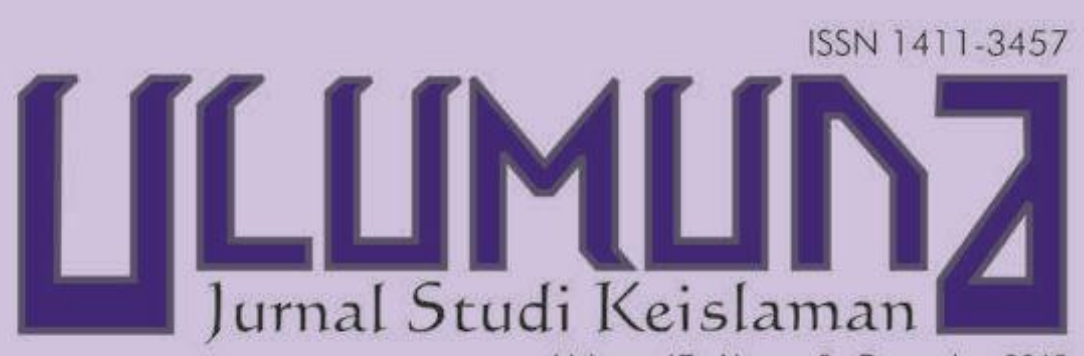

Volume 17· Nomor 2 - Desember 2013

TERAKREDITASI [3, SK Dirjen Dik: Kenmikind Nomor: 56 DIKTIKep 2012. Targgal 24 junt 2012

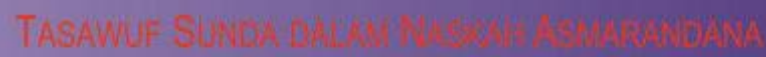
$767(6)$

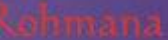

(s):

DALAM TRADISI KEAGM

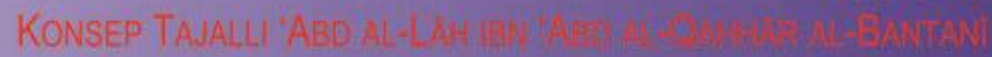

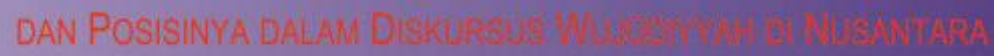

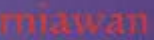

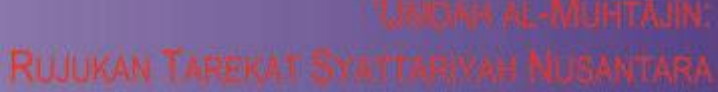

manherit

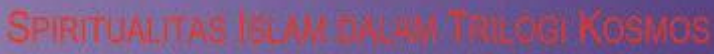

1) thits

YOWMAN:

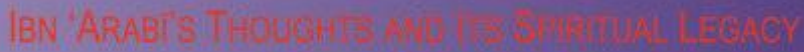

3ेputra

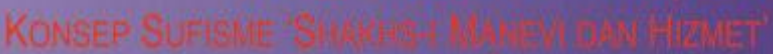

GUIEN

(umayi

Acoxuma

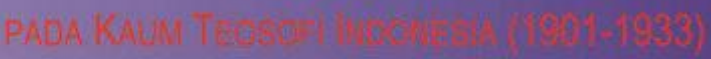

Babei

BASAWUF

Tanany

upinkat 



\section{DAFTAR ISI}

\section{Pedoman Transliterasi}

\section{1-258 • Jajang A Rohmana}

"Tasawuf Sunda dalam Naskah Asmarandana

Ngagurit Kaburu Burit (OR. 7876)”

259-274 • Mashadi

"Konteks dan Corak Mistisisme Islam

dalam Tradisi Keagamaan Masyarakat Gorontalo"

275-302 • Ade Fakih Kurniawan

"Konsep Tajalli 'Abd al-Lāh ibn 'Abd al-Qahhār

al-Bantanī dan Posisinya dalam Diskursus

Wujūdiyyah di Nusantara"

303-322 • Damanhuri

“Umdah al-Muhtàjīin:

Rujukan Tarekat Syattariyah Nusantara"

\section{3-346 • Munawir Haris}

"Spiritualitas Islam dalam Trilogi Kosmos"

347-358 - Hans Abdiel Harmakaputra

"Becoming a Perfect Human:

Ibn 'Arabî's Thoughts and Its Spiritual Legacy"

359-386 • Sulaiman Al-Kumayi

"Konsep Sufisme 'Shakhs-i Manevi dan Hizmet'

Muhammad Fethullah Gülen"

387-420 • Media Zainul Bahri

"Gagasan Pluralisme Agama

pada Kaum Teosofi Indonesia (1901-1933)"

421-440 • Lalu Supriadi

"Studi Komparatif Pemikiran Tasawuf

al-Ghazali dan Ibn Taimiyah"

\section{LAMPIRAN-LAMPIRAN}




\section{PEDOMAN TRANSLITERASI}

\begin{tabular}{|c|c|c|c|c|c|c|}
\hline 1 & $=$ & $\mathbf{a}$ & & $\dot{\varepsilon}$ & $=$ & $\mathrm{g}$ \\
\hline ب & $=$ & $\mathbf{b}$ & & ف & $=$ & f \\
\hline$ت$ & $=$ & $\mathbf{t}$ & & ق & $=$ & $q$ \\
\hline$\dot{H}$ & $=$ & th & & ك & $=$ & $\mathbf{k}$ \\
\hline ج & $=$ & $\mathfrak{j}$ & & J & $=$ & 1 \\
\hline$\tau$ & $=$ & ha & & s & $=$ & $\mathrm{m}$ \\
\hline$\dot{\tau}$ & $=$ & $\mathbf{k h}$ & & ن & $=$ & $\mathbf{n}$ \\
\hline د & $=$ & d & & و & $=$ & $\mathbf{w}$ \\
\hline ذ & $=$ & dh & & ○ & $=$ & $\mathbf{h}$ \\
\hline Ј & $=$ & $\mathbf{r}$ & & $\varepsilon$ & $=$ & , \\
\hline j & $=$ & $\mathbf{z}$ & & ي & $=$ & $\mathrm{y}$ \\
\hline س س س & $=$ & $\mathbf{s}$ & & & & \\
\hline 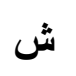 & $=$ & sh & \multicolumn{4}{|c|}{ Untuk Madd dan Diftong } \\
\hline ص & $=$ & ș & i & $=$ & \multicolumn{2}{|c|}{$\bar{a}$ (a panjang) } \\
\hline ض & $=$ & d & إي & $=$ & \multicolumn{2}{|c|}{$\overline{1}$ (i panjang) } \\
\hline b & $=$ & $t$ & 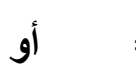 & $=$ & \multicolumn{2}{|c|}{$\bar{u}$ (u panjang) } \\
\hline ظ & $=$ & $\mathrm{z}$ & 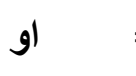 & $=$ & \multicolumn{2}{|c|}{ aw } \\
\hline$\varepsilon$ & $=$ & ‘ & 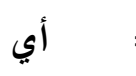 & $=$ & \multicolumn{2}{|l|}{ ay } \\
\hline
\end{tabular}

Contoh penulisan dengan transliterasi:

(a'üdhu bi al-Lāh min al-shaytān al-rajim); اعوذ بالله من الشيطان الرجيم

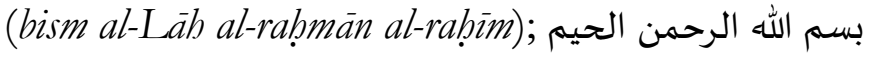

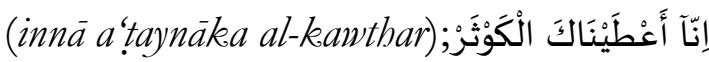

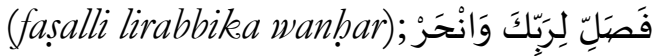

(șabāḥ al-khayr). صبباح الخير 


\title{
STUDI KOMPARATIF PEMIKIRAN TASAWUF AL-GAZĀLI DAN IBN TAIMIYAH
}

\author{
Lalu Supriadi \\ (Fakultas Ilmu Tarbiyah dan Keguruan IAIN Mataram \\ Email: nasabila46@yahoo.com)
}

Abstract: Al-Gazāit plays an important role in purifying Sufism and directing it into the right path of Islam. Prior to his time, many people misunderstood Sufism. While some of them were concerned only with sufi theories but lost its practices, some others simply practiced Sufism without sufficient knowledge. In his time, where splits of religious sects and disintegration spread among Muslims, he emerged to offer his notion that integrates Sufi concepts of intuition, knowledge and spiritual path to achieve the bighest objective of happiness. He bimself reached these sufi paths through several stages in his life and spirituality. Meanwhile Ibn Taymiyya acknowledges the validity of experimental sufi but encourages a method of external examination, namely the basic teachings of Islam, to examine the validity of Sufism. According to him, Sufism is a form of religious expressions that must be built on the Qur'an and Sunna and has to refer to the practices of the Companions.

Abstrak: al-Gazäli berjasa besar dalam melakukan purifikasi ilmu tasawuf dan menariknya kembali ke pangkuan Islam. Sebelum itu banyak orang yang salah memahaminya. Di tengah gejolak dan disintegrasi keislaman antar berbagai sekte dalam tubub umat Islam alGazäli tampil dengan konsepnya yang memadukan antara teori dhawq (rasa/intuisi) ma'rifah dan tharīqah rūhiyah (jalan spiritual) menuju al-sa'ādah (kebahagiaan). Sementara Ibn Taimiyah mengakui keabsahan metode eksperimental tasawuf, tapi ia menyarankan agar tasawuf juga mempergunakan validitas ekesternal untuk menguji kebenaran konsepnya. validitas eksternal yang dimaksud adalab ajaran pokok yang ada dalam Islam. Inti dari pandangan Ibn Taimiyah tentang tasawuf adalah babwa ia (tasawuf) merupakan perpanjangan dari agama Islam yang secara normatif harus bersumber dari al-Qur'an dan Sunnah dan secara historis aplikatif harus merujuk pada keteladanan para sababat.

Keywords: al-Gazāli, Ibn Taimiyah, tasawnf, purifikasi, ma'rifah. 
MENYEJAJARKAN Ibn Taimiyah dengan al-Gazālī dalam ranah pemikiran keislaman khususnya tasawuf adalah menarik. Itu karena sebagian peneliti melihat tipologi pemikiran keduanya sangat berbeda. Al-Gazālī adalah sosok ulama yang berjasa besar dalam melakukan purifikasi ilmu tasawuf dan menariknya kembali ke pangkuan Islam. Sebelum itu banyak orang yang salah memahami tasawuf; ada yang hanya concern dengan sisi teorinya saja tanpa menyentuh sisi praktek spiritualnya sebagaimana yang dilakukan sebagian ulama kalam dan filsafat, ada juga yang hanya menyentuh sisi praktek spiritualnya saja tanpa mau memahami teorinya sehingga muncul para sufi yang hanya mementingkan tampilan fisik saja.

Di tengah gejolak dan disintegrasi keislaman antarberbagai aliran dan sekte dalam tubuh umat Islam al-Gazālī tampil dengan konsep paripurnanya yang memadukan antara teori dhawq (rasa/intuisi) ma'rifah dan tariqah rübiyah (jalan spiritual) menuju al-sa'ádah (kebahagiaan). Karena itu konsep tasawuf yang diperkenalkan al-Gazālī mendapat tempat di hati para ulama dan umat Islam. Al-Gazālī sampai ke tingkatan tersebut setelah melalui berbagai fase dalam kehidupan riil dan spiritualnya. Ini semua menjadikannya sebagai tokoh sufi yang dipuja dan dikenang terus oleh umat Islam. Sementara itu, di sisi lain Ibn Taimiyah diklaim sebagai ulama yang sangat keras memusuhi tasawuf dan mengkritik para sufi. Banyak kritikan dan hujatan dialamatkan kepadanya. Sebut saja Masignon yang menuduh Ibn al-Jawzī dan Ibn Taimiyah sebagai penentang utama tasawuf. ${ }^{1}$ Isu tersebut berhembus demikian kencang dalam dinamika pemikiran keagamaan sehingga banyak dari umat Islam yang terkecoh dan membenarkannya. Namun dalam referensi dan sumber primer yang ditulis langsung oleh Ibn Taimiyah ditemukan fakta sebaliknya bahwa ia memuji kontribusi yang diberikan oleh Shuyükh al-Süfiyah (ulama tasawuf) yang selalu merujuk pada al-Qur'an dan Sunah. Dengan latarbelakang demikian, tulisan ini akan difokuskan pada persoalan bagaimana konsep pemikiran al-Gazālī dan Ibn Taimiyah dalam tasawuf serta komparasi antara pemikiran al-Gazālī dan Ibn Taimiyah.

${ }^{1}$ Ibrāhīm Zaki Khursyid, Dayrat al-Māāarif al-Islāmiyah, jilid 5 (Mesir: Maktabah al-Sya’b, 1969), 274. 


\section{Seting Historis Sosial Intelektual al-Gazālī}

Ia adalah Muḥammad bin Muḥammad bin Aḥmad alias Abū Hāmid. Disebut juga al-Gazālī karena berasal dari Ghazālah nama desa tempat kelahirannya atau Ghazzālī nisbah kepada profesi orang tuanya yang seorang pemintal benang yang dibuat dari wol (bulu domba). Lahir di kota Thūs, nama suatu daerah di Khurasan Iran tahun $450 \mathrm{H}^{2}{ }^{2}$ Di kota Thūs, ia belajar dari Aḥmad bin Muhammad al-Zarīkāni dan Yusuf al-Nassāj, seorang sufi, selanjutnya ia pindah ke Jurjān berguru kepada Abū Nashr al-Ismā'ily seorang ulama yang dikenal wara', takwa dan alim. Ia juga belajar tasawuf dan tarekat kepada Abū 'Alī alQarmidī. Kehausannya dengan ilmu pengetahuan menyebabkannya pindah ke Naisabur dan berguru pada Imam al-Haramayn al-Juwaynī yang saat itu menjabat Kepala Madrasah al-Nizhāmiyah. Di sini, ia bisa mendalami berbagai disiplin ilmu dari guru-guru yang tidak diragukan kapabilitasnya seperti fiqh, ushul fiqh, mantiq, kalam, dan jadal.

Di Naisābūr al-Gazālī sangat produktif menulis berbagai disiplin ilmu pengetahuan, antara lain: Iḅyà 'Ulum al-Dìn, Maqāsid al-Faläsifah, Tahāfut al-Falāsifah, al-Iqtișād fi al-I'tiqād, al-Munqidh min al-D alāl, al-Ma'ärif al-'Aqliyah, al-Tibr al-Masbuk fi Nașīhah alMuluk, Ijjàm al-'Awàm 'an 'ilm al-Kalàm, Mukāshafāt al-Qulub, Minhäj al-'Ábidin, 'Aqidat Abli al-Sunnah, Faysal al-Tafriqah Bayn alIslām wa al-Zindiqah, Musykilāt al-Anwàr, Fadǟih al-Bätiniyah, Bidāyat al-'Amal, Mizān al-'amal, Míyār al-ílm. Tak salah kemudian ia digelari sebagai Hujjah al-Isläm.

Posisi intelektual yang disandangnya tidak membuatnya tenang dan nyaman, namun dalam perjalanan hidupnya ia sampai ke suatu fase di mana ia meragukan kebenaran inderawi yang bersifat primer. Ia meragukan ilmu pengetahuan yang sudah dicapai dan karya-karya ilmiyah yang dihasilkan bahkan menderita penyakit psikologi selama dua bulan, dan sulit diobati. ${ }^{3}$ Karena itu, Al-Gazālī tidak dapat menjalankan tugasnya mengajar di Madrasah Nizhāmiyah. Akhirnya ia meninggalkan

2Khayr al-Dīn al-Zarkali, al-A'lam, jilid 7 (Beirut: Dār 'Ilm li al-Malayīn, 1979), 247 .

3al-Gazālī, al-Munqidh..., 335. 
Bagdad menuju kota Damaskus. Selama kira-kira dua tahun, alGazālī mengembara di kota ini melakukan kegiatan ritual spiritual seperti 'uzlah (mengasingkan diri), riyāạah (olah ruhani), dan mujähadah (kerja keras). Kemudian ia pindah ke Baitul Maqdis Palestina untuk melaksanakan ibadah serupa, setelah itu tergerak hatinya untuk menunaikan ibadah haji dan menziarahi makam Rasulullah. Tak lama berselang akhirnya ia meninggal dunia pada tanggal 12 Jumadi Akhir tahun $505 \mathrm{H}$.

\section{Pemikiran Tasawuf Al-Gazālī}

Dalam perspektif al-Gazālī tasawuf merupakan satu-satunya jalan yang menghantarkan seseorang menuju kebahagiaan hidup di dunia dan akhirat. ${ }^{4}$ Kesimpulan tersebut diperolehnya setelah melalui berbagai dinamika dalam kehidupan spiritual dan intelektualnya. Di samping itu ia juga telah melakukan kajian mendalam terhadap pengaruh dan peran empat disiplin keilmuan terhadap kajian keislaman yang berkembang pesat saat itu; pertama, kalam; kedua, falāsifah; ketiga, bạtiniyyūn; keempat, mutasawwifah. ${ }^{5}$

Pada akhirnya, al-Gazālī sampai ke suatu kesimpulan bahwa kesempurnaan hidup manusia dapat diperoleh dengan mengaktualisasikan kesempurnaan batin. Dan kesempurnaan batin hanya dapat ditempuh dengan jalan tasawuf sehingga alGazālī menjadikan tasawuf sebagai metode, sulūk, baik secara teori maupun praktek.

Dalam perspektif al-Gazālī, tasawuf adalah totalitas hati menuju Allah dan menganggap hina sesuatu selain-Nya. Itu mengacu kepada gerak hati dan perbuatan tubuh. Dalam Ihyā' Ulūm al-Dīn ia menggunakan terma 'ilmu akhirat' untuk menyebut tasawuf di mana ia membaginya menjadi dua; pertama, mu'ämalah, yaitu kondisi-kondisi hati atau penyakit hati dan pengobatannya. Kedua, mukäshafah yaitu tersingkapnya tabir sehingga Allah menjadi jelas sebagaimana mata melihat sesuatu yang tidak diragukan lagi. ${ }^{6}$

4al-Gazālī, al-Munqidh..., 372.

${ }^{5}$ Ibid.

'al-Gazālī, Ibya' 'Ulum al-Din, jilid 1 (Damaskus: Maktabah al'Uthmaniyah, 1352), 3. 
Kalau dicermati karakteristik tasawuf yang dikembangkan alGazālī adalah tasawuf sunni yang bertumpu pada kesucian rohani serta keluhuran budi yang merupakan perwujudan paling otentik dan valid dari religiusitas seseorang. Tasawuf sunni inilah kemudian diterima oleh kalangan luas dan akhirnya mempunyai pengaruh yang begitu kuat di dunia Islam.

\section{Maqāmāt dan Aḅwāl}

Seorang sälik (istilah lain untuk menyebut para sufi) yang meniti jalan menuju Allah terkadang dalam proses pencapaiannya mengalami pengalaman-pengalaman spiritual yang dinamakan maqāmāt (bentuk jamak dari kata maqām) dan a hawāl (bentuk jamak dari kata ḅăl). Jika menempel terus pada sălik dan tak terpisahkan darinya dinamakan maqämät, seperti warna kuning yang menjadi sifat emas yang tak terpisahkan darinya. Tetapi jika menempel hanya sebentar dan cepat sirna maka dinamakan hāl seperti warna kuning (pucat) yang melekat pada muka orang yang ketakutan di mana ketika rasa takutnya hilang maka warna kuning (pucat) itu akan sirna. ${ }^{7}$

Maqāmät diperoleh melalui mujähadah (kerja keras), tadžkiyah al-nafs (penyucian jiwa), dan riyaạdah (olah ruhani) sehingga sālik mampu menundukkan dan melawan hawa nafsunya. Dalam melawan hawa nafsunya seorang sälik dituntut untuk menundukkan irädah-nya demi irädah Allah, tidak menentukan pilihannya demi pilihan Allah, tidak meminta dan mengharap dari seseorang kecuali Allah. Ia berlari dari dunia menuju akhirat dan dari akhirat menuju Tuhannya.

Maqāmàt menurut al-Gazālī adalah olah ruhani (rìyạdah) yang dilakukan sälik dengan mujähadah sampai merasa sempurna pada satu maqām (maqām tertentu) lalu beralih ke maqām yang lain. ${ }^{8}$ Itu semua dilakukan untuk secara bertahap untuk sampai kepada ketinggian spiritual. Sedangkan băl adalah kondisi batin yang suatu ketika bersih dan suatu ketika sebaliknya. Lanjutnya, hăl adalah kondisi di mana hati seseorang berubah, terkadang bersih terkadang sebaliknya. ${ }^{?}$

${ }^{7}$ Ibid., jilid 4, 104.

${ }^{\text {I Ibid., jilid 5, } 16 .}$

${ }^{9}$ Ibid. 
Menurut al-Gazālī, ada enam maqāmāt yang harus dilalui seseorang, yakni: tawbah, zubd, sabr, tawakkal, khawf, dan rajä. Sementara itu, ada dua hăl yang harus dilalui seseorang, yaitu murāqabah dan mạabbah.

Ma'rifat

Dalam perspektif al-Gazālī, konsep ma'rifat merupakan bagian dari finalitas tahapan spiritual seorang sufi. Setelah seorang sufi melewati berbagai tahapan maka sampailah ia pada satu thamroh atau hasil dari perjalanan kesufian tersebut yaitu mahabbah (cinta Allah). Keterikatan antara mahabbah dan ma'rifat dalam pemikiran sufisme amat erat dan tak dapat dipisahkan baik subtansi maupun sifat-sifatnya. Tiada pengenalan yang tidak melahirkan cinta. Ini berlaku dalam setiap tarap spiritual.

Menurut al-Gazālī, proses mengenal Allah tidak dapat dilakukan hanya dengan menggunakan akal sebagaimana yang diyakini oleh para kaum filsafat. Al-Gazālī mengatakan bahwa pengenalan Allah dengan perantara dhawq (intuitif) akan lebih dapat memberikan keyakinan dan ketenangan spiritual dari pada hanya sebatas bersandar dengan akal.

Proses ma'rifat (pengenalan) seseorang kepada Allah untuk mencapai mạ̧abbah berbeda-beda. Al-Gazālī membagi kelompok orang-orang yang sampai pada tingkat ma'rifat dan mahabbah kepada dua tingkatan: pertama, tingkatan seseorang yang kuat dalam márifat, yaitu seseorang yang menjadikan Allah sebagai awal ma'rifatnya dan kemudian dengan márifat itu ia mengenal segala sesuatu yang selain Allah. Kedua, adalah tingkatan seseorang yang lemah ma'rifat-nya, yaitu seseorang yang bermula dengan mengenal ciptaan Allah kemudian dengan ma'rifat-nya ia mengenal Allah.

Untuk sampai pada mahabbah dan márifat yang sempurna kepada Allah, tentunya seorang sufi terlebih dahulu harus melewati berbagi tahapan dan melewati batas fan $\vec{a}$, yaitu tahapan spiritual yang menggambarkan seorang sufi yang telah melakukan proses takhalli (membersihkan diri dan jiwa dari segala macam sifat yang dibenci oleh Allah) dan tahalli (menghiasi diri dan jiwa dengan segala macam sifat yang dipuji oleh Allah). Finalitas dari sebuah mahabbah dan ma'rifat yang 
sempurna adalah terbukanya hijāb (tabir) dan terjadinya tajalli (penampakan Tuhan pada makhluknya). Seorang yang telah sampai pada tahapan ini akan merasa hidupnya terpenuhi oleh cahaya Tuhan.

Menurutnya márifat sebenarnya adalah mengenal Allah. Sarana ma'rifat seorang sufi adalah qalbu, bukan perasaan dan bukan pula akal. Kalbu, menurut al-Gazāti bukanlah bagian tubuh yang dikenal terdapat pada sebelah kiri dada seorang manusia, tapi ia adalah ruh yang merupakan realitas hakekat manusia. ${ }^{10}$ Masih menurutnya, hati bagaikan cermin, sementara ilmu adalah pantulan gambar realitas yang terdapat di dalamnya. Jika cermin hati tidak bening, maka ia tidak dapat memantulkan realitas-realitas ilmu. Dan yang membuat cermin hati tidak bening adalah hawa nafsu tubuh. Sementara zikir kepada Allah, keterpalingan dari tuntutan hawa nafsu serta ketaatan kepadaNya itulah yang justru membuat kalbu bersinar dan cemerlang. ${ }^{11}$

\section{Rasio dan Ma rifat}

Al-Gazālī sangat menjunjung tinggi peran rasio. Dalam tasawuf, rasio menempati posisi kedua setelah akidah karena ia adalah 'ayn al-bashìrah (mata hati) dan nür al-imān (cahaya keimanan) yang dipergunakan untuk mengenal Allah, kebenaran para Rasul dan mengetahui syariat. Peran rasio dalam tasawuf ada dua; Pertama, sebagai syarat untuk sampai kepada ma'rifat melalui tiga hal; memperoleh pengetahuan empiris, riyädlah (olah ruhani) dan kontemplasi. Kedua, menilai dan meluruskan pengalaman-pengalaman ruhani para sufi.

Kashf

Al-Gazālī membedakan ma'rifat yang diperoleh dengan rasio dan indera dan yang diperoleh dengan hati (kashf), yaitu terlimpahnya pengetahuan secara langsung. Ia mendeskripsikannya laiknya ibarat kolam yang digali, lalu kolam tersebut kemungkinan akan dialiri air sungai dari atasnya dan kemungkinan lain bagian bawah kolam akan digali dan tanahnya

${ }^{10}$ al-Gazali, Ihya' ..., jilid 3, 3-4.

${ }^{11}$ Maḥmud Abū al-Fayḍ, Madkhal ila al-Tasānnf, jilid 3 (Mesir: Dār alQawmiyah, t.t.), 11-2 . 
diangkat sampai dasarnya sama rata dengan tempat air yang jernih sehingga airnya muncrat mengeluarkan air yang paling jernih, paling keras dan paling banyak airnya.

Perumpamaan hati seperti kolam dan ilmu pengetahuan seperti air dan indera seperti sungai. Ilmu pengetahuan bisa saja dipancarkan ke hati melalui sungai indera dengan ítibār dan mushāhadāt sehingga dipenuhi ilmu pengetahuan. Dan bisa saja sungai-sungai tersebut ditutup dengan khalwat, 'u§lah dan menutup mata dan beralih/bersandar ke hati yang paling dalam dengan menyucikannya dan mengangkat hijab (tabirnya) sehingga memancar mata air ilmu pengetahuan dari dalam. ${ }^{12}$ Hati memiliki dua pintu: pertama, pintu yang terbuka ke Lauh alMahfuzh dan alam malaikat. Kedua, pintu yang terbuka ke indera yang berpijak pada kesaksian dan kenyataan riil. al-Gazāī menyatakan bahwa ilmu pengetahuan para sufi dan wali didasarkan pada Lauh al-Mahfuzh, sedangkan ilmu pengetahuan para ulama dan orang-orang bijak didasarkan pada indera dan rasio. Dan ilmu para sufi memancar dari hati sedangkan ilmu para ulama memancar dari indera dan rasio. ${ }^{13}$

Para ulama bekerja untuk memperoleh ilmu pengetahuan yang sama-sama dihasilkan para wali dengan cara yang berbeda. Di satu sisi para ulama mengambilnya dari luar dengan menggunakan indera, sedangakan para wali memperoleh ilmu tersebut dengan cara memancarkannya dari dalam hati. Ilmu jenis pertama adalah ma'rifat empirik yang diperoleh berdasarkan indera dan rasio dan yang kedua dengan nama ma'rifat kashfiyah yang datang dari dalam hati setelah menghilangkan kotoran maksiat dan menyingkap tabir syahwat, sehingga terlimpahkan segala sesuatu yang tersurat di Lauhul Mahfuzh. ${ }^{14}$ Ilmu yang pertama disebut ittibār (pembelajaran) dan istibshār (penalaran) sedangkan yang kedua disebut dhawq (intuisi) dan kashf (limpahan langsung dari Allah tanpa perantara) dengan cara ilham atau wahyu tetapi ilham khusus untuk para wali dan wahyu khusus untuk para nabi. Jadi, kashf adalah cara untuk mengetahui hakekat yang menyampaikan seseorang kepada al-ilm al-yaqini

12al-Gazālī, Ibya' ..., jilid 3, 20.

${ }^{13}$ Ibid.

14Ibid., 21. 
(ilmu yang menghasilkan keyakinan yang tidak ada keraguan sedikitpun padanya).

\section{Kebahagiaan}

Al-Gazālī menyusun teori ma'rifat-nya dengan al-sa'ädah (kebahagiaan). Menurutnya, kelezatan dan kebahagiaan manusia yang tertinggi terletak pada ma'rifat Allah. Ia menyandarkan teorinya pada analisa psikologis dan analogi logika. Ia berkata:

Kebahagiaan pada segala sesuatu terletak pada kelezatannya dan kelezatannya terletak pada tuntutan tabiatnya dan tabiat sesuatu terletak pada keselarasannya dengan penciptaannya/kejadiannya. Kelezatan mata adalah memandang gambar-gambar yang indah begitu juga anggota badan yang lain. Sedangkan hati adalah jalan untuk mencapai ma'rifat keyakinan karena kelezatannya terletak pada pengetahuannya kepada Allah yaitu ma'rifat yang diciptakan hati karenanya. Tidak ada yang meragukan bahwa kebahagiaan yang diperoleh berdasarkan ma'rifat Allah lebih besar dari kebahagiaan yang lain. Manakala kadar ma'rifatnya lebih agung dan mulia maka ma'rifat-nya lebih detil dan halus dan kelezatan yang ditimbulkan lebih kuat dan mengesankan. Seperti seorang yang ingin merasa bertemu menteri maka kenikmatannya menjadi lebih besar jika tiba-tiba ia bertemu raja. ${ }^{15}$

Menurut al-Gazālī, kebahagiaan adalah tujuan akhir jalan para sufi sebagai buah pengenalan terhadap Allah. Jalan menuju kebahagiaan itu adalah ilmu beserta amal sebagaimana pernyataannya: "Seandainya engkau memandang ke arah ilmu, niscaya engkau akan melihatnya begitu lezat sehingga ilmu itu dipelajari karena manfaatnya. Engkau juga mendapatkannya sebagai sarana menuju akhirat serta kebahagiaan, dan juga sebagai jalan mendekatkan diri kepada Allah. Namun hal ini mustahil tercapai kecuali dengan ilmu dan amal. ${ }^{16}$

\section{Seting Historis Sosial Intelektual Ibn Taimiyah}

Ia adalah Aḥmad bin 'Abd al-Halīm bin 'Abd al-Salām bin Ab̄̄ al-Qāsim bin Khidr bin Muḥammad Bin Taimiyah alias Ibn Taimiyah, dikenal juga dengan nama panggilan Abū al-Abbās dan Taqiy al-Dīn. Lahir di Harran nama suatu daerah yang kini merupakan bagian dari wilayah Turki pada hari Senin tanggal 10

15al-Gazālī, Kimiya’ al-Sa'adah (Mesir: Dar al-Kitab al-Arabi, 1354), 15.

16al-Gazālī, al-Munqidh..., 372 
Rabiul Awal tahun $661 \mathrm{H} / 1263 \mathrm{M}$ atau sekitar 5 tahun setelah invasi Tatar ke Bagdad, kota monumental yang kala itu menjadi pusat ilmu dan peradaban. ${ }^{17}$ Masa kecilnya dihabiskan di tanah kelahirannya sampai berumur 7 tahun. Kemudian peristiwa invasi Tatar menyebabkan keluarganya terpaksa berpindah domisili ke Damsyiq (kini Suriah).

Ia tumbuh dewasa di keluarga yang dikenal religius dan sangat menjunjung tinggi nilai-nilai intelektualisme. Ayahnya bernama Șihāb al-Dīn bin 'Abd al-Halīm adalah seorang ulama hadis dan fiqh yang menganut mazhab Hanbali (Ahmad bin Hambal). Mengajar secara terjadwal di Masjid Umawiyah yang kala itu tempat mangkalnya ulama-ulama besar. Ia juga menjabat ketua Shaykh Dār al-Hadīs al-Sukkariyah dan langsung menetap di sana dan di sana pula akhirnya ayahnya meninggal dunia dan dikuburkan di kuburan para ulama sufi. Ayahnya meninggal dunia ketika Ibn Taimiyah berumur 21 tahun. Lalu ia diasuh oleh ibunya.

Dari keluarga intelektual ini, ia mewarisi sifat dan karakter orang tuanya yang selanjutnya menyebabkan ia brilian dan genius. Dalam perkembangan intelektualnya ia banyak menimba ilmu dari guru-gurunya yang sangat disegani sampai mencapai angka 200 orang. ${ }^{18}$ Di antaranya orang tuanya sendiri yang mengajarnya langsung ilmu fiqh dan hadis. Lalu Zain al-Dīn Aḥmad Bin 'Abd al-Dāyim Bin Ni 'mah al-Maqdisī, Ibn Abī alYusri, al-Kamāl Bin 'Abd, al-Majd Bin `Asākir, Jamāl Yaḥyā Bin al-Shairafî, Aḥmad Bin Abi al-Khair, al-Qāsim al-Arbīlī, Fakhr al-Dīn Bin al-Bukhārī, Kamāl 'Abd al-Raḥim, Abu al-Qāsim Bin Allān, Aḥmad Bin Syaibān. Ibn Qudāmah al-Maqdisī, Nur alDīn Bin `Ali Bin 'Abd al-Bashīr, Jamāl al-Dīn al-Qazuin̄i. Tak pelak perjalanan intelektualnya antara Damsyiq dan Kairo menyebabkan banyak orang menimba ilmu darinya. Diantara muridnya yang terkenal adalah Syamsu al-Dīn Muḥammad Bin Qayyim al-Jauziyah (691-751). 104.

${ }^{17} I b n$ Kathīr, al-Bidāyah wa al-Nihāyah, jilid 1 (Beirut: al-Ma'arif, 1966),

${ }^{18} \mathrm{Ibn}$ 'Abd al-Hadi, Al-'Uqud al-Durriyah fì Manāqib Shaykh al-Islām Ibn Taymiyah, studi naskah: Muhammad Hamid al-Faqi (Kairo: Maktabah Hijazi, 1356), 3 . 
Ibn Taimiyah tidak saja dikenal sebagai ulama yang concern dalam dunia akademik, tetapi ia juga seorang pejuang sejati yang mengangkat pedang untuk membela Islam dan mengusir penjajah dan musuh-musuh Islam sama seperti yang dilakukan oleh ulama-ulama terkemuka lainnya semisal 'Izzal-Din Bin 'Abd al-Saläm, Ibn Taimiyah dan Muby al-Din al-Nawawiy. Semua ini membuatnya memiliki hubungan dekat dengan penguasa saat itu yaitu Sulthan al-Nāshir Muhammad bin Qalāwün. Bahkan ia diangkat menjadi penasehat spiritual dan keagamaannya.

Setelah kekuatan politik Sultan Muhammad bin Qalāwùn mulai melemah di tambah dengan adanya faktor-faktor lain sebagaimana disebutkan diatas ia beberapa kali mendapatkan fitnah dan cobaan dari orang-orang yang iri, dengki dan berseberangan pemikiran dengannya. Ibn Taimiyah pernah dituduh berpaham mujassimah (berkeyakinan bahwa Allah itu memiliki jisim (tubuh) seperti makhluk) dan musyabbihah (berkeyakinan Allah menyerupai mahluk). Hal ini bermula dari penulisan kitab al-Risālah al-Hamawiyah yang dimaksudkan sebagai jawaban atas pertanyaan orang-orang tentang ayat-ayat al-Qur'an yang berisi sifat-sifat Allah dan oleh Ibn Taimiyah di jawab bahwa ayat-ayat tersebut harus di pahami apa adanya tanpa harus ditakwil. Jawaban tersebut ternyata menimbulkan reaksi yang keras dari para ulama yang berseberangan dengannya terutama al-Qādli (hakim) Jalāl al-Dīn Hanafi. ${ }^{19}$ Resistensi dari para ulama eksoteris menyebabkannya harus keluar masuk penjara, tapi penjara bagi Ibn Taimiyah tidak menjadi halangan untuk berkarya dan berjuang menyampaikan gagasan dan pemikirannya.

Ibn al-Wardi (w. 749 H) mengkalkulasikan bahwa Ibn Taimiyah dalam sehari semalam menulis 4 lembar dan diperkirakan jumlah buku yang dikarangnya mencapai jumlah 500 jilid $^{20}$. Kitab-kitab tersebut antara lain: Majmu' Fatāwà alKubrā, al-Qawā'id al-Nürāniyah, al-Furqān Baina Auliyä' al-Rabmān Wa Auliyà' al-Syaithān, Amrādl al-Qulūb Wa Iläjuhā, al-Tubfah al-

${ }^{19}$ Muhamamad Abū Zahrah, Ibn Taymiyah; Ashrubu wa Hayātubu (Beirut: Dār al-Fikr al-Arabī, 1946), 59-60.

${ }^{20}$ Muhammad Yūsuf, Tarikh Ibn al-Wardi, jilid 7 (Mesir: Maktabah alSa'adah: 1951), 786. 
Irāqiyah Fi A'māl al-Qulub, al-Ubüdiyah, Darajāt al-Yaqin, al-Risālah al-Tadmuriyah, al-Risalah al-Hamawiyah, Bugyat al-Murtāb, Ibthäl Wabdat al-Wujüd, al-Tawassul $W$ a al-W asilah, al-Washiyah al-Kubrā, al-Risälah al-Ladunniyah, Minhäj al-Sunnah al-Nabawiyah, Syarh alAqìdah al-Ashfahāniyah, al-Jawāb al-Shahīh Liman Baddala Din alMasih, al-Raddu 'Alā al-Nashārā, al-Raddu 'Alā al-Manthiqiyyìn, Naqdlu al-Manthiq, Syarbu Hadits Innamā al-A'māl Bi al-Niyyāt, alSiyäsah al-Syar'iyah Fi Ishlähi al-Rä̀'T Wa al-Ra'iyyah.

Ibn Taimiyah meninggal Tak lama berselang ia keluar dari penjara pada malam Senin 20 Dzulkaidah tahun $728 \mathrm{H}^{21}$.

\section{Perspektif Ibn Taimiyah dalam Tasawuf}

Dalam literatur bahasa terdapat beberapa pendapat mengenai asal kata tasawuf. Pertama, kata süff dialamatkan kepada mereka yang memakai pakaian yang terbuat dari süff (bulu domba/wol). Kedua, sekelompok orang yang tinggal di teras masjid di kota Madinah yang dikenal dengan ahl al-Shuffah. Ketiga, orang yang suci dan bersih hatinya dari perbuatan hati yang tercela. Ibn Taimiyah sepakat dengan pendapat pertama, yaitu kata tasawuf berasal dari kata süff, yaitu orang yang menggunakan bulu domba/wol).22 Namun demikian Ibn Taimiyah tidak setuju jika tampilan fisik saja dijadikan parameter untuk mengukur dan menilai ketasawufan seseorang tetapi yang tak kalah penting adalah bagaimana ia membersihkan dan menyucikan hatinya dari segala sifat yang tercela. Oleh karenanya, dalam karya-karyanya ditemukan penggunaan terma yang berbeda-beda untuk menyebut para sufi, di antaranya fuqarā', zubhād, sālikìn, asḥāb al-qalbi wa Arbāb al-Aḥwāl, asḥāb alTasawuf al-Mashrü' atau asḥäb al-Süfiyah. ${ }^{23}$

Sekalipun Ibn Taimiyah menggunakan beragam istilah untuk menyebut para sufi namun ia tidak memiliki definisi yang definitife. Menurut hemat saya, tidak adanya definisi yang definitif mengenai tasawuf dalam versi Ibn Taimiyah disebabkan karena ia tidak ingin terkecoh oleh slogan dan tampilan fisik saja

${ }^{21}$ Abū Zahrah, Tarikh Mazāhib ..., jilid 2, 434-5.

${ }^{22}$ Ibn Taymiyyah, Al-Furqān Bayn Awliyā' al-Raḅmān wa Awliyà' alShaythān (Kuwait: Maktabah al-Ṣabih, 1378), 36.

23Ibn Taymiyyah, Majmu’ Fatawa ..., jilid 10, 368. 
tetapi harus dibuktikan dengan praktek. Jika menunjuk pada cara ibadah dan praktek yang sesuai dengan syara' maka ia adalah tasawuf yang benar sebagaimana dipraktekkan para sufi genenerasi awal. Kalau tidak maka ia adalah tasawuf yang menyimpang. Ia berkata: "para wali Allah adalah orang-orang mukmin yang bertakwa baik ia dikatakan faqì, süfi, faqïh, 'älim (ilmuan), täjir (pedagang), șāni (pembuat barang), amì (raja), häkim (penguasa) atau yang lainnya". ${ }^{24}$

Ibn Taimiyah mengklasifikasikan tasawuf menjadi dua: pertama, tasawuf sunni atau sering disebutnya tasawuf masyrü, yaitu yang diperbolehkan mengikutinya yang sudah muncul embrionya sejak masa awal mula Islam yaitu generasi para sahabat, yang kemudian dikembangkan oleh Junaid Bin Muḥammad al-Bagdādi (w. 297 H) di Bagdad, Abū Sulaymān alDārāni (w. 210) di Syam, Dhu al-Nūn al-Mișri (w. $245 \mathrm{H}$ ) di Mesir, al-Harits al-Muhāsibi (w 243 H) di Bagdad di mana dalam teori dan prakteknya mereka semua menjadikan al-Qur'an dan Sunnah sebagai sumber. Mereka ini disebut syuyūkh al-Shüfiyah oleh Ibn Taimiyah. Kedua, tasawuf bid'ah yaitu tasawuf yang sudah kemasukan unsur-unsur asing dalam teori dan prakteknya. Dalam memahami dan mempraktekkan tasawuf mereka mencampuradukkan ajaran Islam dengan teori dan praktek yang tidak dikenal sebelumnya seperti memasukkan unsur filsafat dalam tasawuf. Contoh ulama sufi jenis ini adalah Ibn Arabi dan pengikutnya. Ibn Taimiyah mengkritik tajam dan mengecam para sufi jenis kedua ini. Dalam mengomentari pemikiran Ibn Arabi ia berkata: Ibn Arabi bukanlah tipe abli sufi yang memiliki spirit intelektual apalagi mengikuti al-Qur'an dan Sunnah. ${ }^{25}$ Ia juga berkata: mereka ini tercela di sisi Allah, Rasul-Nya dan para wali Allab. ${ }^{26}$

Ia membuat klasifikasi yang lebih rinci lagi mengenai tipologi penganut tasawuf; Pertama, para sufi ahlu al-Sunnah generasi awal yang dalam teori dan praktek tasawufnya merujuk pada alQur'an dan Sunnah. Kedua, para sufi ahlu al-Sunnah yang mencampuradukkan tasawuf dengan ilmu Kalam tetapi tidak

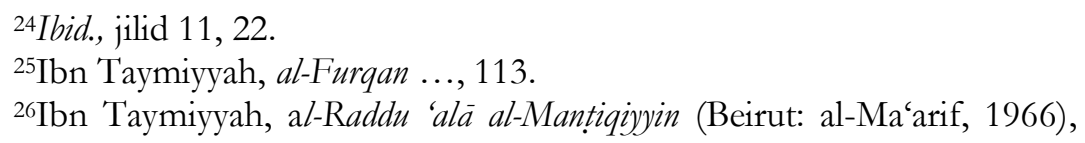


dipengaruhi filsafat. Ketiga, para sufi yang mencampuradukkan tasawuf dengan filsafat.

Maqāmāt dan Aḅwāl

Aḥwāl dan maqāmāt versi Ibn Taimiyah milik semua kalangan. Tidak ada dikhotomi antara khāsh (orang-orang khusus) dan 'am (orang-orang umum), antara zhahir (yang nyata) dan batin (tidak tampak) sebagaimana pendapat sebagian para sufi karena ini menimbulkan kesulitan dalam memahami perkataan para penganut tasawuf. Dalam perspektif Ibn Taimiyah setidaknya ada tujuh maqāmàt yang harus dilalui oleh seseorang; Pertama, taubat, Kedua, tawakkal, Ketiga, zubd, Keempat, ridà, Kelima, shabr, Keenam, khauf. Ketujuh, rajä. Sementara hạl terdiri dari maḅabbah.

Mairifat

Sebagian penganut tasawuf berpendapat bahwa ma'rifat hanya bisa diperoleh ketika seseorang sudah mencapai tahapan atau derajat tertentu dalam tasawuf dengan alasan jika ma'rifat bisa diperoleh tanpa ilmu dan usaha maka takliff (pembebanan manusia terhadap beberapa amal ibadah) itu tidak ada gunanya/manfaatnya. Sementara itu Ibn Taimiyah berpendapat sebaliknya bahwa ma'rifat merupakan fithrah manusia yang dibawa sejak lahir, bisa diperoleh oleh siapapun baik muslim atau non muslim tanpa melalui perantaraan ilmu dan usaha, dan sarana untuk mencapai ma'rifat adalah qalbu (hati). Sedangkan taklif diperoleh melalui perantaraan para Rasul.

Pada sisi lain qalbu (hati) bisa saja menerima ilmu tetapi dengan usaha, proses dan perantara dalam pencariannya yang selanjutnya dinamakan ilm mathlub (ilmu yang dicari). Namun ada juga jenis ilmu yang diperoleh tanpa melakukan pencarian dan proses tetapi langsung diberikan Allah kepada seseorang yang dinamakan ilm maubub (ilmu yang diberikan). Jika seseorang menginginkan suatu ilmu maka sebenarnya hatinya yang bertindak sebagai pemandu dengan dibantu oleh dua indera yaitu telinga (untuk mendengar) dan mata (untuk melihat). Kelebihan orang yang menggunakan hati dan pendengarannya adalah ia bisa mengetahui sesuatu yang abstrak dan bersifat spiritual seperti keimanan, percaya dengan yang gaib dan lain sebagainya. 
Sedangkan kelebihan hati dari mata dan telinga adalah ia bisa memikirkan segala sesuatu dengan sendirinya. Dan tujuan penciptaan qalbu (hati) adalah agar seseorang ber-Dzikir (mengingat Allah). Jadi Sarana untuk mencapai ma'rifat adalah qalbu (hati) dengan dibantu oleh pendengaran dan penglihatan. Dan qalbu berkedudukan sebagai sarana sementara anggota tubuh yang lain adalah pendukung ${ }^{27}$.

Ibn Taimiyah membuktikan kebenaran konsep tersebut dengan logika dan pengalaman hidup yang sering dialaminya di mana manusia tidak mungkin ada tanpa pencipta, bangunan tidak mungkin berdiri sendiri tanpa adanya orang yang membangunnya, bekas kaki/jejak tidak mungkin ada tanpa adanya orang yang menginjak tempat tersebut dan seterusnya. Sedangkan kejadian alam yang tidak sering terjadi seperti kilat, petir dan gempa bumi semua itu merupakan faktor pendukung ma'rifat karena kebiasaan manusia jika melihat seseuatu yang asing dan baru mereka berzikir (mengingat Allah) dan ber-tasbih (menyucikan Allah). Jika manusia sadar bahwa ia tidak menciptakan dirinya sendiri dan tidak diciptakan oleh orang lain maka ia sampai pada suatu kesimpulan bahwa ada zat pencipta yaitu Allah. Cara penggalian hakekat seperti ini dinamakan ilmu al-Qulub ${ }^{28}$.

Ma 'rifat jenis ini dinamakannya al-Iman al-Mujmal dan ia tidak berdiri sendiri tetapi harus disertai dengan al-Iman al-Mufasshal yaitu nilai-nilai normatif yang bersumber dari al-Qur'an dan alSunnah. Ma rifat seperti ini akan mengantarkan seseorang kepada kebahagiaan di dunia dan itu harus ditopang oleh pelaksanaan ibadah yang diperintahkan dan mengikuti jalan kenabian. Kemudian pada saat itu seseorang akan sampai pada tujuan paling tinggi yaitu kebahagiaan di akhirat sehingga ia bisa melihat apa yang tidak pernah dilihat mata dan mendengar apa yang tidak pernah didengar telinga dan apa yang tidak pernah terlintas di benak seseorang ${ }^{29}$.

27Ibn Taymiyyah, Jami ' al-Rasa'il (Riyadl: Maktabah al-Madani, 1389), 11

28Ibn Taymiyyah, Minhaj ..., jilid 3, 100.

29Ibn Taymiyyah, Majmu' Fatawa ..., jilid 2, 24. 


\section{al-Wilāyah dan al-Karāmah}

Wali Allah adalah seseorang yang dekat dengan Allah. Standar untuk mengukur kedekatan seseorang adalah keimanan dan ketakwaannya kepada Allah. Semakin bertambah keimanan dan ketakwaan yang diperbuat maka semakin dekat ia kepada Allah. Dalam perspektif Ibn Taimiyah Wali Allah terbagi menjadi dua; Pertama, sabiqun muqarrabun yaitu orang yang mendekatkan diri kepada Allah dengan mengerjakan ibadah yang nawäfil (hukumnya sunnat) setelah mengerjakan yang wajib. Jadi mereka mengerjakan yang wajib dan sunnat serta meninggalkan yang haram dan makruh. Kedua, ashhäb al-Yamin yaitu orang yang mendekatkan dirinya kepada Allah dengan mengerjakan ibadah yang wajib saja. Mereka mengerjakan yang wajib dan meninggalkan yang haram serta tidak memaksakan dirinya untuk mengerjakan yang sunnah dan tidak memaksakan dirinya untuk meninggalkan yang mubah ${ }^{30}$.

Titik temu antara wilayah dan nubuwab terletak pada kejadian luar biasa yang diberikan Allah kepada seseorang yang mencapai derajat tersebut. Kalau kejadian luar biasa yang diberikan kepada nabi maka dinamakan mujizat sedangkan kejadian luar biasa yang diberikan kepada wali dinamakan karämah. Mu'jizat dimaksudkan sebagai bukti yang mendukung kebenaran risalah yang diemban seorang Nabi.

Ibn Taimiyah mengklasifikasikan kejadian luar biasa menjadi tiga. Pertama, mukhātabāt yaitu seseorang bisa mendengar apa yang tidak didengar oleh orang lain. Kedua, musyāhadāt yaitu seseorang bisa melihat apa yang tidak dilihat oleh orang lain baik dalam sadar atau bermimpi. Ketiga, mukāsyafah yaitu seseorang mengetahui apa yang tidak diketahui oleh orang lain. Semua bentuk kejadian luar biasa ini dalam perspektif Ibn Taimiyah di namakan kashf atau mukäsyafah.

Derajat al-wilayah tidak mesti menuntut adanya kejadian luar biasa yang terjadi pada orang yang mencapai derajat tersebut. Bisa jadi seseorang adalah wali Allah tetapi tidak memiliki kejadian yang luar biasa sebagaimana bisa saja terjadi kejadian luar biasa pada seseorang yang sering mengerjakan perbuatan

${ }^{30}$ Qs. al-Wāqi'ah: 7-14. 
maksiat dan ia bukanlah seorang wali Allah. Dengan ini maka wali Allah adalah seorang mukmin yang bertakwa ${ }^{31}$.

\section{Perbandingan antara Pemikiran Tasawuf al-Gazālī dan Ibn Taimiyah}

Setelah memaparkan pemikiran tasawuf al-Gazālī dan Ibn Taimiyah, penulis menemukan adanya beberapa kesamaan konsep antara kedua ulama pada hal-hal berikut ini; Pertama, bahwa al-Gazālī dan Ibn Taimiyah bersama-sama melakukan purifikasi terhadap ajaran tasawuf dengan mengembalikannya ke sumbernya yang orisinil yaitu nash-nash al-Qur'an dan sunah Rasul serta praktek para sahabat. Kedua, al-Gazālī dan Ibn Taimiyah bersama-sama menolak konsep shatahät (pernyataan teopatis) para penganut tasawuf dengan alasan hal tersebut membuka ruang bagi orang-orang yang tidak berkompeten untuk secara sengaja mengungkapkan dirinya sendiri dengan ungkapan yang samar, tidak jelas, tertutup, sulit dipahami dengan alasan kekhususan untuk dirinya saja. Disamping itu konsep tersebut mengaburkan perbedaan antara sang Khäliq (pencipta) dengan makhlūq (yang diciptakan). Terlebih lagi ekses tersebut ternyata banyak yang disalahgunakan, misalnya bila seorang (wali atau syekh) sudah dianggap sampai pada tahapan ittihäd maka ia berada di luar batas-batas syariat dalam arti ia tidak memiliki kewajiban untuk melaksanakan apa yang telah ditetapkan syariat. Ketiga, al-Gazālī dan Ibn Taimiyah bersamasama menyusun teori ma'rifat-nya dengan al-sa'ädab (kebahagiaan) di mana menurut al-Gazālī kelezatan dan kebahagiaan manusia yang tertinggi terletak pada márifat Allah. Sementara Ibn Taimiyah menyatakan bahwa kebahagiaan tertinggi terletak pada realisasi 'ubudiyah (penghambaan) kepada Allah.

Sementara itu perbedaan konsep antar keduanya terlihat pada hal-hal berikut ini; Pertama, Tasawuf adalah jalan yang ditempuh al-Gazālī untuk keluar dari dekadensi pemikiran yang sempat membuatnya skeptis (ragu) terhadap segala bentuk pengetahuan termasuk keyakinan. Semua proses ini mewarnai kehidupan pemikirannya untuk mencari márifat Allah yang lalu

\footnotetext{
${ }^{31}$ Qs. Yūnus: 62-63.
} 
menghantarkannya kepada keyakinan yang final dan valid. Sementara Ibn Taimiyah menjadikan al-Qur'an dan Sunnah sebagai satu-satunya jalan yang bisa mengantarkan seseorang kepada ma'rifat Allah. Kedua, dalam konsep tasawuf al-Gazālī mempraktekkan khalwah (menyendiri selama beberapa hari dengan berzikir kepada Allah) sampai mendapatkan tajalli (penampakan Allah). Sementara Ibn Taimiyah sangat menentang praktek khalwah yang dilakukan banyak orang. Dalil yang sering dipergunakan oleh sebagian ahli tasawuf dengan meniru praktek Rasulullah yang pernah tabannuth di gua Hira ditentang oleh ia dengan alasan setelah Nabi Muhammad diutus sebagai nabi, ia tidak pernah mempraktekkan tahannuth lagi bahkan para sahabat tidak pernah melakukannya sama sekali. Seandainya taḩannuth itu disyariatkan maka pasti umatnya diperintahkan untuk mempraktekkannya

\section{Catatan Akhir}

Jika sebelumnya tasawuf berupaya menenggelamkan diri pada Allah melalui tokoh-tokohnya semisal Hasan al-Bashri (khauf), Rabi`ah al-Adawiyah (bub al-lläh), Abū Yazid AlBusthāmi (fanà), al-Hallaj (bülū̃), dan kemudian berkembang dengan munculnya tasawuf bercorak filsafat dengan tokohtokohnya Ibn Arabi (waḥdat al-wujūd), Ibn Sabi in (ittiḩād), dan Ibn Faridl (bubb al-Lah, fana', dan wabdat al-shühüd) yang memfokuskan diri pada bakekat serta terkesan mengenyampingkan syariat, maka konsep tasawuf yang ditawarkan al-Gazālī berhasil mengkolaborasikan syariat (fiqh), dan hakekat (tasawuf).

Secara umum Ibn Taimiyah mengakui keabsahan metode eksperimental tasawuf, tapi ia menyarankan agar Tasawuf juga mempergunakan validitas eksternal untuk menguji kebenaran konsepnya. validitas eksternal yang dimaksud adalah ajaran pokok yang ada dalam Islam. Inti dari pandangan Ibn Taimiyah tentang Tasawuf adalah bahwa ia (tasawuf) merupakan perpanjangan dari agama Islam yang secara normatif harus bersumber dari al-Qur'an dan Sunnah dan secara historis applikatif harus merujuk pada keteladanan para sahabat. Wa alLäh a lam bi al-sawàb. 


\section{Daftar Pustaka}

Abd al-Hādi, Ibn. 1366. Al-'Uqūd al-Durriyah fì Manāqib Shaykh al-Islām Ibn Taymiyyah, studi naskah: Muhamamad Hāmid alFaqi. Kairo: Hijāzi.

Abū al-Faidl, Maḥmud. t.t. Madkhal ilā al-Tasawuf. Mesir: Dār alQawmiyah.

Abdullah Otta, Yusno. Tasawuf dan Tantangan Perubahan Sosial. Lemlit IAIN Mataram, vol. 14 no. 2 Desember 2010, 389412.

Ashur, Sa'id 'Abd al-Fattah. 1403. al-Harakah al-Salibiyah. Juz.1. Kuwait: Dār al-Qalam.

Abū Zahrah, Muhammad. 1946. Ibn Taymiyab; Ashrubu Wa Hayātubu. Beirut: Dār al-Fikr al-Arabi. . 1948. Tārikh Mažāhib al-Islämiyah. Beirut: Dār alFikr al-Arabi.

Bāsil, Saìd. t.t. Manhaj al-Babthi 'an al-Ma'rifat Inda al-Gazälì. Beirut: Dār al-Kitāb al-Lubnāni.

Dunyā, Sulaymān. 1965. Al-Haqiqah fi Naz̧ar al-Gazāìi. Mesir: Dār al-Ma’ārif.

al-Gazālī, Abū Hāmid. 1354. Kimiyà̃’ al-Sa‘ādah. Mesir: Dār alKitab al-Arabi.

. 1392. Al-Munqidh min al-palāl. Kairo: Dār al-

Nashr. . 1352. Ibyā' 'Ulum al-Din. Damaskus: Maktabah alUthmāniyah.

1355. Al-Risālah al-Ladunniyah, studi naskah:

Abdul Halim Maḥmud. Kairo: Maktabah al-Jundi.

Kathir, Ibn. 1966. Al-Bidāyah wa al-Nihāyah. Beirut: al-Ma’ārif.

Kutbi, Muḥammad Bin Syākir. 1951. Fawāt al-Wafiyāt, vol. 1. Mesir: Maktabah al-Sa'ādah.

Khursyid, Ibrahim Zāki. 1969. Dāyrat al-Ma'ärif al-Islāmiyah. Mesir: Maktabah al-Sya'b.

Rifāici, Aḥmad Farid. 1355. Al-Gazălì. Damaskus: Maktabah alHalabi.

Subki, Tāj al-Din. 1379. Ṭabaqāt al-Shāfíriyah. Beirut: Dār al-Kitāb al-Lubnāni. 
Suhrawardi. 1366. Awārif al-Ma'ärif. Kairo: Dār al-Kutub alHaditsah.

Taymiyyah, Ibn. 1355. Sharḥ al-'Aqidah al-Asfahäniyah. Damaskus: Maktabah al-Halabi.

Ma’ārif.

. 1966. al-Raddu 'ala al-Mantiqiyyin. Beirut: al. 1389. Jāmi‘ al-Rasāìl. Riyādl: Maktabah alMadani.

1378. al-Furqān Bayn Awliyā' al-Rahmān wa Awliyä', al-Shaytān, Kuwait: Maktabah al-Shabih. . 1389. al-Sufiyah wa al-Fuqarä,', studi naskah: Dr. Muhammad Jamil Gāzi. Riyādl: Maktabah al-Madani. . t.t. Majmu' Fatāwa, Studi Naskah: Dr. Muḥammad Rasyād Sālim KSA: Mathba'ah Riyādl.

'Uthmān, 'Abd al-Karīm. t.t. Al-Imām al-Gąălì. Damaskus: Dar al-Fikr.

Yūsuf, Muhammad. 1951. Tärikh Ibn al-Wardi. Mesir: Maktabah al-Sa'ādah.

Zarkali, Khayr al-Dīn. 1979. Al-A'làm, jilid 7. Beirut: Dār Ilmi Li al-Malāyin. 